\title{
PENINGKATAN KEMAMPUAN BERPIKIR KRITIS DAN HASIL BELAJAR MELALUI PENERAPAN MODEL DISCOVERY LEARNING DALAM PEMBELAJARAN TEMATIK KELAS 4 SD
}

\author{
Yulita Windarti', Slameto'2, Eunice Widyanti $S^{3}$ \\ ${ }^{1}$ Pendidikan Guru Sekolah Dasar, Universitas Kristen Satya Wacana, 292014171@student.uksw.edu \\ ${ }^{2}$ Pendidikan Guru Sekolah Dasar, Universitas Kristen Satya Wacana slameto@staff.uksw.edu \\ ${ }^{3}$ Pendidikan Guru Sekolah Dasar, Universitas Kristen Satya Wacana eunice.widyanti.@gmail.com
}

\section{INFO ARTIKEL}

Riwayat Artikel:

Diterima: 17-03-2018

Disetujui: 05-04-2018

Kata Kunci:

Discovery Learning

Berpikir Kritis

Hasil Belajar

\section{A. LATAR BELAKANG}

Pendidikan adalah aspek penting dalam kehidupan manusia. Dengan adanya pendidikan, manusia dapat mengembangkan kemampuan berpikirnya sehingga akan mampu bersaing di era globalisasi. Kemampuan-kemampuan yang diperlukan dalam bersaing di era global sudah diberikan mulai dari jenjang pendidikan yang paling dasar yaitu Sekolah dasar (SD). Siswa sekolah dasar mulai mengalami perkembangan dalam tingkat berpikirnya, oleh karena itu diperlukan dorongan agar siswa mampu untuk mengembangkan kemampuan berpikir kritisnya dalam memecahkan suatu masalah serta setelah menerima pengetahuan yang baru. Kemampuan berpikir kritis dapat dikatakan sebagai suatu bentuk berpikir yang perlu untuk dikembangkan, dengan tujuan untuk memecahkan suatu masalah, merumuskan kesimpulan, mengumpulkan berbagai kemungkinan, dan membuat keputusan untuk mendapatkan penyelesaian (Yoanda, Amrina, dan Shislina, 2015:4). Dalam hal ini guru memiliki peran penting dalam menyampaikan materi pembelajaran, seorang guru diharapkan dapat menarik perhatian dan memotivasi siswanya agar siswa mempunyai kemampuan berpikir kritis dan berpartisipasi aktif serta memfasilitasi siswa dalam mengembangkan kreatifitas dan kemandirian siswa pada pembelajaran yang sesuai dengan bakat, minat,

\section{ABSTRAK}

Abstrak: Jenis penelitian ini adalah penelitian tindakan kelas. Tujuan dari penelitian ini tuk meningkatkan kemampuan berpikir kritis dan hasil belajar siswa dalam pembelajaran bahwa penerapan model Discovery Learning dapat meningkatkan kemampuan berpikir kritis tinggi dan sedang pada siklus I adalah 30\%, meningkat di siklus II menjadi $82 \%$. Ketercapaian ketuntasan hasil belajar siswa pada pra siklus adalah 38\%, meningkat di siklus I Discovery Learning Model can improve the critical thinking skill and learning outcomes of the students. Precentage of critical thinking skill in very high and moderate category, in cycle was 30\%, and increased in cycle I/ 82\%. The achievement of students learning completeness at pre-cycle was 38\%, increasing in cycle / to $68 \%$, increasing again in cycle // to $85 \%$.

dan perkembangan diri siswa terutama dalam pembelajaran tematik.

Sore (2015:5), mengatakan bahwa "berpikir kritis adalah proses intelektual berdisiplin yang secara aktif dan cerdas mengonsepsualisasikan, menerapkan, menganalisis, mensintesiskan, dan/atau mengevaluasi informasi yang dikumpulkan atau dihasilkan melalui observasi, pengalaman, refleksi, nalar atau komunikasi sebagai panduan mengenai apa yang dipercaya dan tindakan yang diambil". Berpikir kritis juga dapat dikatakan sebagai kemampuan untuk berpikir dalam level yang kompeks dan menggunakan proses analisis dan evaluasi. kemampuan berpikir kritis tidak akan muncul begitu saja, kemampuan berpikir kritis membutuhkan stimulus atau rangsangan yang tepat (Purba, 2015:61). Kemampuan berpikir kritis menjadi penting bagi siswa dikarenakan hal ini akan diperlukan dalam kegiatan pembelajaran serta dalam kehidupan di masyarakat. Kemampuan berpikir kritis perlu dikembangkan melalui proses pembelajaran, namun tidak semua proses pembelajaran akan secara otomatis mengembangkan kemampuan berpikir kritis siswa. Hanya proses pembelajaran yang dalam kegiatannya melakukan diskusi, banyak memberikan kesempatan siswa untuk berpendapat, mendorong kerjasama dalam mengkaji dan menemukan pengetahuan yang akan mengembangkan kemampuan berpikir kritis siswa. 
Terdapat 4 indikator kemampuan berpikir kritis sebagai fokus dari penelitian yang dilakukan.

Ke-4 indikator tersebut yaitu: 1) memfokuskan pertanyaan. 2) menganalisis argumen; 3) mengobservasi dan mempertimbangkan laporan hasil observasi; 4) menuliskan kesimpulan. Indikator kemampuan berpikir kritis tersebut harus terpenuhi selama kegiatan pembelajaran berlangsung. Kemampuan berpikir kritis siswa yang rendah tentu akan berdampak pada hasil belajar yang diperoleh siswa.

Hasil belajar merupakan kemampuan yang dimiliki oleh masing-masing siswa yang berupa kemampuan konitif, afektif dan psikomotor (Kunandar, 2014:62). Dahar (2011:118) menambahkan bahwa hasil belajar dapat juga dikatakan sebagai kemampuan atau keterampilan yang dimilki oleh siswa baik itu kemampuan kognitif, afektif maupun kemampuan psikomotor setelah siswa selesai dalam melakukan kegiatan pembelajaran. Hasil belajar dijadikan sebagai tolok ukur keberhasilan siswa yang dinyatakan dalam penilaian yang terdiri dari 3 aspek, yaitu aspek kognitif, afektif dan psikomotorik. Siswa dikatakan berhasil dalam belajar jika siswa dapat memahami materi yang disampaikan serta mengalami perkembangan dan kemajuan dalam kegiatan pembelajarannya. Hasil belajar yang baik akan diperoleh siswa jika siswa benarbenar serius untuk belajar. Hasil belajar dapat dilihat dengan melakukan kegiatan evaluasi sebagai data pembuktian yang akan menunjukkan tingkat kemampuan siswa dalam mencapai tujuan pembelajaran (Widayanti dan Slameto, 2016:187). Dalam kenyataannya hasil belajar merujuk pada pencapaian hasil belajar yang diukur dengan tugastugas yang harus dijawab atau diselesaikan oleh siswa dengan tujuan untuk mengukur kemajuan belajar dengan tes dalam bentuk nilai.

Hasil dari observasi awal yang dilakukan menunjukkan bahwa proses pembelajaran pada pembelajaran tematik belum optimal. Dalam kegiatan pembelajaran yang dilakukan materi yang diterima siswa hampir semuanya berasal dari apa yang disampaikan oleh guru. Siswa kurang didorong untuk aktif atau cenderung pasif dalam mengikuti pembelajaran sehingga mengakibatkan pembelajaran kurang menarik dan membosankan yang mengakibatkan kemampuan berpikir kritis siswa masih rendah dan berdampak terhadap hasil belajar siswa yang rendah. Diketahui bahwa kriteria ketuntasan minimal (KKM) pada pembelajaran tematik kelas $4 \mathrm{SD}$ di salah satu sekolah dasar di Kota Salatiga adalah $\geq 75$. Siswa dikatakan mencapai KKM jika nilainya sudah mencapai 75 atau lebih. Hasil ulangan tengah semester pembelajaran tematik kelas 4 SD yang bersangkutan, semester I tahun ajaran 2016/2017 menunjukkan bahwa dari 34 siswa terdapat $13(38,2 \%)$ siswa yang sudah mencapai KKM, sedangkan $21(61,76 \%)$ siswa belum mencapai KKM. Dengan rentang nilai tertinggi 90 dan nilai terendah 26,7.

Berdasarkan hasil observasi awal yang dilakukan ini peneliti merasa perlu digunakan suatu model pembelajaran yang mampu untuk meningkatkan hasil belajar serta kemampuan berpikir kritis siswa terhadap materi yang dipelajarinya. Salah satu model pembelajaran yang mampu untuk menumbuhkan kemampun berpikir kritis siswa dan nantinya tentu akan berdampak terhadap peningkatan hasil belajar siswa adalah model pembelajaran Discovery Learning. Model pembelajaran Discovery Learning menjadi salah satu alternatif untuk mengatasi permasalahan yang sudah dipaparkan sebelumnya. Model Discovery Learning merupakan suatu model pembelajaran dimana siswa akan menemukan dan menyelidiki sendiri konsep pengetahuan yang akan dipelajari kemudian akan mengkonstruk pengetahuan itu untuk memahami maknanya, sehingga apa yang ditemukan oleh siswa akan bertahan lama dalam ingatan, tidak akan mudah untuk dilupakan (Kristin, 2016:91). Dengan belajar penemuan siswa juga akan lebih mampu untuk berpikir kritis sehingga siswa bisa untuk memecahkan permasalahan-permasalahan yang dihadapinya.

Sintak atau langkah-langkah yang harus dilakukan dalam menerapkan model Discovery Learning antara lain: 1) Stimulation (stimulasi/pemberian rangsangan); 2) Problem Statement (pernyataan /identifikasi masalah); 3) Data Collection (pengumpulan data); 4) Data Processing (pengolahan data); 5) Verification (pembuktian); 6) Generalization (menarik kesimpulan/ generalisasi) (Nurrohmi, Utaya, Utomo , 2017:1309). Dengan demikian langkah-langkah kegiatan dengan menggunakan model Discovery Learning adalah dimulai dengan siswa akan menerima sebuah pertanyaan, dimana pertanyaan tersebut akan merangasang siswa untuk berpikir, menyimak penjelasan dari guru, mengamati sebuah gambar untuk memperoleh informasi, merumuskan masalah, kemudian dilanjutkan dengan menarik sebuah hipotesis, mengolah data, mengumpulkan, memverifikasi dan menarik kesimpulan (Rumini dan Wardani, 2016:24). Dalam kegiatan pembelajaran dengan menerapkan model Discovery Learning siswa akan terlibat secara aktif selama proses pembelajaran berlangsung, guru hanya akan berperan sebagai fasilitator yang membimbing siswa dalam melakukan kegiatan-kegiatan selama proses pembelajaran.

Berdasarkan uraian tersebut, maka yang menjadi fokus dalam penelitian ini adalah apakah penerapan model Discovery Learning dapat meningkatkan kemampuan berpikir kritis dan hasil belajar siswa kelas 4 SD pada pembelajaran tematik? 


\section{B. METODE PENELITIAN}

Jenis penelitian yang dilakukan yaitu penelitian tindakan kelas (PTK). Penelitian tindakan kelas yaitu penelitian yang dimaksudkan untuk memperbaiki suatu kegiatan pembelajaran di kelas. Penelitian ini merupakan salah satu upaya guru untuk memperbaiki dan meningkatkan mutu kegiatan pembelajaran dikelas (Slameto, 2015: 148). Metode penelitian yang digunakan adalah metode penelitian tindakan kelas dengan menggunakan teori dari Kemmis dan Mc Tagart (dalam Arikunto, 2010:17). Penelitian ini terdiri dari tahapan prosedur penelitian yaitu: 1) rencana tindakan; 2) pelaksanaan tindakan; 3) observasi; 4) refleksi.

Penelitian tindakan kelas dilakukan dalam dua siklus dengan masing-masing siklus terdiri dari dua kali pertemuan dan disetiap akhir siklus akan diberikan soal evaluasi. Penelitian ini dilakukan di salah satu sekolah dasar negeri di Kota Salatiga pada kelas 4 yang berjumlah 34 siswa.

Data hasil dari penelitian akan diperoleh dari data hasil observasi dan data hasil belajar siswa. Dalam penelitian ini data yang diperlukan antara lain: 1) data hasil dari aktifitas guru dalam menerapkan model Discovery Learning yang diperoleh melalui lembar observasi keterlaksanaan model pembelajaran Discovery Learning; 2) data hasil dari aktifitas siswa dalam menerapkan model Discovery Learning yang diperoleh melalui lembar observasi keterlaksanaan model pembelajaran Discovery Learning; 3) data hasil dari kemampuan berpikir kritis siswa yang diperoleh melalui lembar observasi sesuai dengan indikator kemampuan berpikir kritis; 4) hasil belajar siswa yang diperoleh melalui tes evaluasi yang diberikan di setiap akhir siklus; 5) hasil belajar afektif siswa yang diperoleh melalui observasi selama kegiatan pembelajaran berlangsung; 6) hasil belajar psikomotor siswa yang diperoleh melalui observasi selama kegiatan pembelajaran berlangsung.

Indikator keberhasilan dalam penelitian ini dapat dijabarkan sebagai berikut:

1. Indikator keberhasilan kemampuan berpikir kritis siswa diukur dengan perolehan skor siswa pada kategori kemampuan berpikir kritis sedang, tinggi dan sangat tinggi mencapai 80\% dari seluruh jumlah siswa.

2. Indikator keberhasilan hasil belajar siswa dapat dilihat dari jumlah siswa yang mendapatkan nilai lebih dari KKM yaitu $\geq 75$, minimal 80\% dari seluruh jumlah siswa.

\section{HASIL DAN PEMBAHASAN}

Kegiatan perencanaan dalam siklus I dan II dilakukan mulai dari menyusun Rencana Pelaksanaan Pembelajaran (RPP) sampai dengan menyusun lembar observasi dan soal evaluasi. Selanjutnya pelaksanaan penelitian dilakukan sesuai dengan rencana awal yaitu dalam satu siklus terdiri dari dua kali pertemuan. Kegiatan awal dilakukan dengan mempersiapkan siswa secara fisik dan psikis, berdoa, melakukan presensi, apersepsi dan menyampaikan tujuan pembelajaran. Kegiatan inti dilakukan sesuai dengan sintak atau langkah-langkah dari model Discovery learning. Kegiatan inti yang dilakukan dengan menerapkan model Discovery Learning dimulai dengan memberikan contoh gambar yang ditampilkan melalui PPT untuk menimbulkan suatu pertanyaan dalam pikiran siswa, kemudian dilanjutkan dengan bertanya jawab terkait dengan gambar yang ditampilkan, membagi siswa menjadi beberapa kelompok untuk melakukan kegiatan percobaan dan diskusi kelompok, menyampaikan hasil dari diskusi kelompok, guru membimbing siswa untuk menarik kesimpulan. Kegiatan akhir dilakukan dengan melakukan evaluasi pembelajaran, menarik kesimpulan dan doa penutup. Observasi dilakukan untuk memperoleh data aktifitas guru dan siswa selama proses pembelajaran berlangsung, juga untuk memperoleh data hasil dari kemampuan berpikir kritis siswa, hasil belajar afektif dan hasil belajar psikomotor. Selanjutnya refleksi adalah untuk mengetahui kekurangan-kekurangan yang ada pada kegiatan pembelajaran yang telah dilakukan untuk selanjutnya dilakukan perbaikan.

Terdapat 20 aspek yang di observasi dari aktifitas guru mulai dari perencanaan sampai penutup, sehingga skor maksimal yang diperoleh dalah 80. Hasil dari observasi aktifitas guru pada siklus I dan II dengan menerapkan model Discovery Learning dijabarkan secara lebih jelas dalam tabel 1.

TABEL 1

\begin{tabular}{ccc} 
DATA HASIL OBSERVASI AKTIFITAS \\
GURU DENGAN MENERAPKAN MODEL \\
\begin{tabular}{c}
\multicolumn{2}{c}{ DISCOVERY LEARNING } \\
\hline Pertemuan
\end{tabular} & Siklus I & Siklus II \\
\cline { 2 - 3 } & Jumlah & Jumlah \\
& Skor & Skor \\
1 & 69 & 76 \\
2 & 70 & 77 \\
Total Skor & 139 & 153 \\
Rata-rata & 69,5 & 76,5 \\
Kriteria & Baik & Sangat baik \\
\hline
\end{tabular}

Berdasarkan Tabel 1 dapat dilihat bahwa rata-rata skor aktifitas guru dalam proses pembelajaran dengan menerapkan model Discovery Learning pada siklus I memiliki rata-rata 70, tergolong dalam kategori baik. Peneliti berupaya untuk menerapkan dan melaksanakan proses pembelajaran sesuai dengan rencana pelaksanaan pembelajaran yang sebelumnya telah disusun, tetapi masih ada beberapa hal yang perlu untuk diperbaiki. Hasil dari observasi aktifitas guru dalam siklus II memiliki rata-rata 76,5 tergolong dalam kategori sangat baik. Dari hasil data yang diperoleh dalam siklus II menunjukkan bahwa hasil dari 
observasi aktifitas guru mengalami peningkatan dari siklus sebelumnya.

Selain melakukan observasi terhadap aktifitas guru peneliti juga melakukan observasi terhadap aktivitas siswa selama kegiatan pembelajaran berlangsung dengan menerapkan model Discovery Learning. Terdapat 19 aspek yang harus di observasi mulai dari perencanaan sampai dengan penutup, sehingga skor maksimal yang diperoleh adalah 76 . Hasil dari observasi aktivitas siswa selama kegiatan pembelajaran berlangsung dengan menerapkan model Discovery Learning secara lebih jelas dijabarkan dalam tabel 2.

TABEL 2

DATA HASIL OBSERVASI AKTIFITAS SISWA DENGAN MENERAPKAN MODEL DISCOVERY LEARNING

\begin{tabular}{ccc}
\hline Pertemua & Siklus I & Siklus II \\
\cline { 2 - 3 } & $\begin{array}{c}\text { Jumla } \\
\text { h Skor }\end{array}$ & $\begin{array}{c}\text { Jumlah } \\
\text { Skor }\end{array}$ \\
1 & 63 & 70 \\
2 & 63 & 72 \\
$\begin{array}{c}\text { Total } \\
\text { Skor }\end{array}$ & 126 & 142 \\
$\begin{array}{c}\text { Rata- } \\
\text { rata } \\
\text { Kriteria }\end{array}$ & 63 & 71 \\
\hline
\end{tabular}

Hasil dari penilaian aktifitas siswa dalam proses pembelajaran dengan menerapkan model Discovery Learning pada siklus I pertemuan 1 dan 2 memperoleh rata-rata skor 63, yang berada pada kategori baik. Peneliti berupaya untuk menerapkan dan melaksanakan proses pembelajaran sesuai dengan rencana pelaksanaan pembelajaran yang sebelumnya telah disusun, tetapi masih ada beberapa hal yang perlu untuk diperbaiki. Hasil dari observasi aktifitas siswa dalam siklus II pertemuan 1 dan 2 memperoleh skor rata-rata skor 71, dan tergolong dalam kategori sangat baik. Dari hasil data yang diperoleh dalam siklus II menunjukkan bahwa hasil dari observasi aktifitas siswa mengalami peningkatan dari siklus sebelumnya.

\section{Berpikir Kritis}

Data hasil dari kemampuan berpikir kritis siswa diperoleh melalui observasi dengan menggunakan lembar observasi. Kemampuan berpikir kritis siswa diperoleh dengan menjumlahkan seluruh skor dari 4 indikator kemampuan berpikir kritis. Untuk lebih jelasnya data hasil kemampuan berpikir kritis dalam siklus I dan II dijabarkan pada tabel 3.

\begin{tabular}{|c|c|c|c|c|}
\hline \multicolumn{5}{|c|}{$\begin{array}{c}\text { TABEL } 3 \\
\text { PERBANDINGAN HASIL KEMAMPUAN BERPIKIR KRITIS SISWA SIKLUS I DAN }\end{array}$} \\
\hline Kategori & Frekuensi & Presentase & Frekuensi & Presentase \\
\hline Sangat tinggi & o & o\% & 6 & $18 \%$ \\
\hline Tinggi & 4 & $12 \%$ & 12 & $35 \%$ \\
\hline Sedang & 6 & $18 \%$ & 10 & $29 \%$ \\
\hline Rendah & 22 & $65 \%$ & 6 & $18 \%$ \\
\hline Sangat Rendah & 2 & $6 \%$ & o & O\% \\
\hline Jumlah & 34 & $100 \%$ & 34 & $100 \%$ \\
\hline Skor Tertinggi & \multicolumn{2}{|c|}{89} & \multicolumn{2}{|c|}{94} \\
\hline Skor Terendah & \multicolumn{2}{|c|}{44} & \multicolumn{2}{|c|}{61} \\
\hline Rata-rata & \multicolumn{2}{|c|}{61,4} & \multicolumn{2}{|c|}{78,7} \\
\hline
\end{tabular}

Berdasarkan data pada Tabel 3 dapat dilihat bahwa terjadi peningkatan dari siklus I ke siklus II terhadap kemampuan berpikir kritis siswa. Hasil data diperoleh dengan menjumlahkan seluruh indikator kemampuan berpikir kritis kemudian diperoleh data seperti pada Tabel 1. Dapat diketahui dengan menerapkan model Discovery Learning kemampuan berpikir kritis siswa dapat meningkat dalam setiap sikusnya, hal ini dibuktikan dengan presentase dalam setiap kategori kemampuan berpikir kritis mengalami peningkatan yang cukup signifikan. Presentase ketuntasan kemampuan berpikir kritis siswa dalam kategori sangat tinggi, tinggi dan sedang sebesar pada siklus I sebesar 30\% kemudian meningkat disiklus II menjadi $82 \%$. Skor rata-rata yang diperoleh pada siklus I adalah 61,4 kemudian setelah dilakukan tindakan pada siklus II meningkat menjadi 78,7.

\section{Ketuntasan Hasil Belajar}

Ketuntasan hasil belajar siswa diperoleh melalui tes evaluasi yang diberikan di setiap akhir pembelajaran dalam siklus I dan II, sedangkan ketuntasan hasil belajar pra siklus diperoleh melalui nilai dari tes tengah semester 1 siswa kelas 4 . Untuk lebih jelas data dari ketuntasan hasil belajar siswa pada pembelajaran tematik siswa kelas 4 SD dapat dilihat dalam tabel 4. 
TABEL 4

PERBANDINGAN HASIL BELAJAR TEMATIK SISWA PADA PRA SIKLUS, SIKLUS I, DAN SIKLUS II

\begin{tabular}{|c|c|c|c|c|c|c|c|}
\hline \multirow[t]{2}{*}{ No } & \multirow{2}{*}{$\underset{n}{\text { Ketuntasa }}$} & \multicolumn{2}{|c|}{$\overline{\text { Pra Siklus }}$} & \multicolumn{2}{|c|}{ Siklus I } & \multicolumn{2}{|c|}{ Siklus II } \\
\hline & & $\begin{array}{c}\text { Frekuen } \\
\text { si }\end{array}$ & $\begin{array}{c}\text { Presenta } \\
\text { se }\end{array}$ & $\begin{array}{c}\text { Frekuen } \\
\text { si }\end{array}$ & $\begin{array}{c}\text { Presenta } \\
\text { se }\end{array}$ & $\begin{array}{c}\text { Frekuen } \\
\text { si }\end{array}$ & $\begin{array}{c}\text { Presenta } \\
\text { se }\end{array}$ \\
\hline 1. & Tuntas & 13 & $38 \%$ & 23 & $68 \%$ & 29 & $85 \%$ \\
\hline \multirow[t]{2}{*}{2.} & Tidak Tuntas & 21 & $62 \%$ & 11 & $32 \%$ & 5 & $15 \%$ \\
\hline & Jumlah & 34 & $100 \%$ & 34 & $100 \%$ & 34 & $100 \%$ \\
\hline \multicolumn{2}{|c|}{ Skor Tertinggi } & \multicolumn{2}{|c|}{90} & \multicolumn{2}{|c|}{85} & \multicolumn{2}{|c|}{90} \\
\hline \multirow{2}{*}{\multicolumn{2}{|c|}{$\begin{array}{l}\text { Skor Terendah } \\
\text { Rata-rata }\end{array}$}} & \multicolumn{2}{|c|}{26,7} & \multicolumn{2}{|c|}{50} & \multicolumn{2}{|c|}{65} \\
\hline & & \multicolumn{2}{|c|}{71,11} & \multicolumn{2}{|c|}{74,26} & \multicolumn{2}{|c|}{78} \\
\hline
\end{tabular}

Berdasarkan tabel dapat diketahui bahwa penerapan model Discovery Learning mampu meningkatkan hasil belajar siswa. Sebelum dilakukan adanya tindakan atau pra siklus rata-rata hasil belajar siswa adalah 71,11 dan ketuntasan belajar $38 \%$ atau ada 13 siswa yang tuntas dari jumlah keseluruhan siswa 34 . Dari hasil tersebut menunjukkan bahwa pada pra siklus hasil belajar siswa masih jauh dari harapan peneliti, karena siswa yang memperoleh nilai sesuai dengan KKM yaitu $\geq 75$ belum mencapai $80 \%$ dari jumlah seluruh siswa. Setelah dilakukan tindakan pada siklus I hasil belajar siswa mengalami peningkatan. Rata-rata hasil belajar siswa menjadi 74,26 dengan presentase ketuntasan siswa $68 \%$. Ketuntasan hasil belajar siswa kembali mengalami peningkatan setelah dilakukan tindakan pada siklus II, rata-rata yang diperoleh adalah 78 dengan presentase ketuntasan sebesar $85 \%$. Setelah dilakukan tindakan pada siklus II ini presentase ketuntasan hasil belajar siswa sudah sesuai dengan harapan peneliti yaitu sudah lebih dari $80 \%$ dari jumlah keseluruhan siswa memperoleh nilai diatas KKM.

\section{PEMBAHASAN}

Berdasarkan data hasil dari penelitian, dapat diketahui bahwa pelaksanaan pembelajaran tematik dengan menerapkan model pembelajaran Discovery Learning mampu untuk meningkatkan kemampuan berpikir kritis siswa sehingga juga berdampak pada meningkatnya hasil belajar siswa. Langkah-langkah dari model pembelajaran Discovery Learning terbukti mampu untuk meningkatkan kemampuan berpikir kritis siswa, sintak atau langkah-langkah tersebut meliputi: 1) Stimulation; 2) Problem Statement; 3) Data Collection; 4) Data Processing, 5) Verification; 6) Generalization. Hal ini dibuktikan dengan meningkatnya perolehan data dari hasil observasi dan tes evaluasi pada siklus I ke Siklus II. Secara umum dapat dikatakan bahwa keterlaksanaan kegiatan pembelajaran tematik dengan menerapkan model pembelajaran Discovery Learning pada siklus I dan II ini sudah sesuai dengan harapan peneliti.

Peningkatan kemampuan berpikir kritis siswa dibuktikan dengan peningkatan presentase kemampuan berpikir kritis pada siklus I ke siklus II dalam setiap kategorinya. Pada kategori kemampuan berpikir kritis sangat tinggi meningkat sebanyak $18 \%$, kategori tinggi meningkat sebanyak 23\%, pada kategori sedang meningkat sebanyak 11\%, pada kategori rendah presentase menurun sebanyak $47 \%$, dan pada kategori sangat rendah menurun sebanyak 6\%. Terjadinya peningkatan kemampuan berpikir kritis ini juga berdampak pada peningkatan hasil belajar siswa dari siklus I ke siklus II. Ketuntasan hasil belajar siswa sebelum adanya tindakan atau pra siklus ke siklus I meningkat sebanyak 30\%, kemudian dari siklus I ke siklus II ketuntasan hasil belajar siswa meningkat sebanyak $17 \%$.

Berdasarkan dari hasil data yang diperoleh dapat dikatakan bahwa dengan menerapkan model Discovery Learning terbukti mampu untuk meningkatkan kemampuan berpikir kritis dan hasil belajar siswa, hasil dari penelitian ini sejalan dengan penelitian yang telah dilakukan sebelumnya. Berdasarkan penelitian terdahulu yang dilakukan oleh Masrida, dkk (2016) serta Rosdiana, Boleng, Susilo (2017), yang meneliti tentang pengaruh model pembelajaran Discovery Learning terhadap ketrampilan berpikir kritis dan hasil belajar siswa. Hasil dari penelitian yang dilakukan menunjukkan bahwa ada keterkaitan antara penerapan model pembelajaran Discovery Learning dengan kemampuan berpikir kritis dan hasil belajar siswa. Hasil penelitian ini menunjukkan terjadi peningkatan kemampuan berpikir kritis serta hasil belajar siswa.

Penelitian selanjutnya dilakukan oleh Mujib dan Slameto (2017). Hasil penelitian yang dilakukan menunjukkan hasil yang sama dengan penelitian yang dilakukan oleh Rosarina, Sudin dan Sujana (2016). Hasil dari penelitian yang dilakukan menunjukkan hasil bahwa dengan menerapkan model Discovery Learning mampu untuk meningkatkan hasil belajar siswa.

\section{E. SIMPULAN DAN SARAN}

Berdasarkan hasil dari tindakan yang dilakukan oleh peneliti, maka peneliti menarik kesimpulan: 1) penerapan model Discovery Learning dapat meningkatkan aktifitas guru dalam pembelajaran tematik, hal ini terbukti dari peningkatan rata-rata dan presentase keberhasilan aktifitas guru dari siklus I ke 
siklus II; 2) penerapan model Discovery Learning dapat meningkatkan aktifitas siswa dalam pembelajaran tematik, hal ini terbukti dari peningkatan rata-rata dan presentase keberhasilan aktifitas siswa dari siklus I ke siklus II; 3) kemampuan berpikir kritis siswa meningkat setelah diterapkan model Discovery Learning, hal ini terbukti dari meningkatnya skor siswa terhadap kemampuan berpikir kritis mulai dari siklus I ke siklus II; 4) hasil belajar siswa pada pembelajaran tematik dengan menerapkan model Discovery Learning meningkat secara signifikan. Peningkatan ini dapat dilihat mulai dari pra siklus, siklus I dan siklus II, yang ditunjukkan dengan presentase ketuntasan yang terus meningkat dalam setiap siklusnya.

Sehubungan dengan hasil dari penelitian tindakan kelas yang dilakukan peneliti memberikan saran dalam pelaksanaan proses pembelajaran antara lain: 1) bagi guru, pelaksanaan kegiatan pembelajaran dengan menerapkan model Discovery Learning dapat dijadikan sebagai salah satu alternatif untuk dapat meningkatkan kemampuan berpikir kritis dan hasil belajar siswa; 2) kemampuan berpikir kritis menjadi penting bagi siswa, dikarenakan kemampuan berpikir kritis akan menunjang siswa dalam menguasai materi pembelajaran; 3) bagi sekolah, hasil dari penelitian dengan menerapkan model Discovery Learning ini tidak hanya bisa diterapkan dalam pembelajaran tematik, melainkan bisa juga diadaptasi terhadap pembelajaran yang lainnya dan menyesuaikan pembelajaran tersebut dengan model Discovery Learning.

\section{UCAPAN TERIMAKASIH}

Dengan ini penulis mengucapkan terimakasih kepada Bapak Prof. Dr. Slameto, M.Pd selaku dosen pembimbing 1 dan Ibu Eunice Widyanti S., S.Pd., M.Pd selaku dosen pembimbing 2 yang telah membimbing dan memberi arahan sehingga penulis dapat menyelesaikan tugas akhir dengan baik.

\section{DAFTAR RUJUKAN}

[1] Arikunto S. (2010). Penelitian Tindakan Kelas. Jakarta: Bumi Aksara.

[2] Dahar R W. (2011). Teori-Teori Belajar dan Pembelajaran. Bandung: Erlangga.

[3] Kristin, F. (2016). Analisis Model Pembelajaran Discovery Learning Dalam Meningkatkan Hasil Belajar Siswa SD. Jurnal Pendidikan Dasar PerKhasa , Vol. 2, No. 1 (90-98).

[4] Kunandar. (2014). Penilaian Autententik (Penilaian Hasil Belajar Pesdik Berdasar Kurikulum 2013) . Jakarta: Pt. Raja Grafindo Persada.

[5] Masrida, Hala , Y., \& Taiyeb, A. (2016). Pengaruh Model Pembelajaran Discovery Terhadap Ketrampilan Berfikir Kritis Dan Hasil Belajar IPA Kelas VIII Mtsn Libureng Kabupaten Bone. Jurnal Bionature, Vol 17, No 02 (81-87).

[6] Mujib, A. A., \& Slameto. (2017). Penggunaan Model Pembelajaran Discovery Learning Untuk Meningkatkan Hasil Beajar IPA Siswa Kelas 4 SD. Jurnal Pendidikan Indonesia, Vol. 3, No.4
[7] Nurrohmi, Y., Utaya, S., \& Utomo, D. H. (2017). Pengaruh Model Pembelajaran Discovery LearningTerhadap Kemampuan Berpikir Kiritis Mahasiswa. Jurnal Pendidikan, Vol. 2, No. 10 (1308-1314).

[8] Purba, R. T. (2015). Sebuah Tinjauan Mengenai Stimulus Berpikir Kritis Bagi Siswa Sekolah Dasar. Scholaria, Vol. 5 No. 3 (59-64).

[9] Rosarina, G., Sudin, A., \& Sujana, A. (2016). Penerapan Model Discovery Learning untuk Meningkatkan Hasil Belajar Siswa pada Materi Perubahan Wujud Benda . Jurnal Pena Ilmiah, Vol 1. No 1 (371-380).

[10] Rosdiana, Boleng, D. T., \& Susilo. (2017). Pengaruh Penggunaan Model Discovery Learning Terhadap Kemampuan Berpikir Kritis dan Hasil Belajar Siswa. Jurnal Pendidikan: Teori, Penelitian dan Pengembangan, Vol 2. No 8 (1060-1064).

[11] Rumini \& Wardani, N. S. (2016). Upaya Peningkatan Hasil Belajar Tema Berbagai Pekerjaan Melalui Model Discovery Learning Siswa Kelas 4 SDN Kutoharjo 01 Pati Kabupaten Pati Semester 1 Tahun Ajaran 2014/2015. Sholaria, Vol 6, No 1 (19-40).

[12] Slameto. (2015). Metodologi Penelitian. Salatiga: Satya Wacana University Press.

[13] Sore, A. D. (2015). Efektifitas Model Pembelajaran Berbasis Masalah Dalam Mengoptimalkan Ketrampilan Berpikir Kritis dan Hasil Belajar Siswa. Vox Edukasi, Vol. 6, No. 1 (1-15).

[14] Widayanti, E. R., \& Slameto. (2016). Pengaruh Penerapan Metode Team Games Tournament Berbantuan Permainan Dadu Terhadap Hasil Belajar IPA. Scholaria, Vol. 6, No. 3 (182-195).

[15] Yoanda, F., Amrina, Z., \& Shislina, R. (2015). Peningkatan Kemampuan Berpikir Kritis dan Hasil Belajar Siswa Kelas 4 Melalui Model Discovery Learning pada Pembelajaran Matematika di SDN 10 Sungai Sapih Padang. Jurnal Fakultas Pendidikan Universitas Bung Hatta, Vol 1, No 5 ( 1-12).

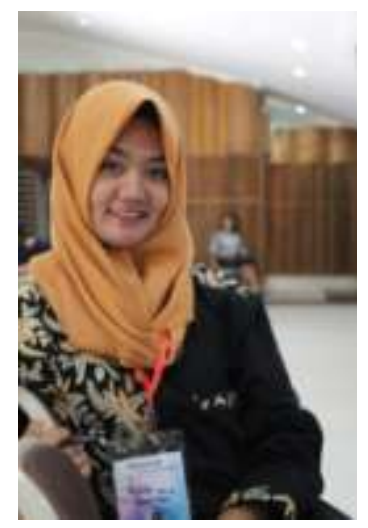

\section{PROFIL PENULIS UTAMA}

Penulis bernama lengkap "YULITA WINDARTI". Lahir di Desa Tening Kecamatan Wonoboyo Kabupaten Temanggung Jawa Tengah pada tanggal 04 Juli 1995 dari pasangan Slamet Iskandar dan Paryati. Pendidikan sekolah dasar dimulai dari SDN Semen Kecamatan Wonoboyo pada tahun 2001-2007. Setelah itu melanjutkan pendidikan sekolah menengah ke SMPN 1 Candiroto pada tahun 2007-2010 dan terakhir di SMK N 1 Temanggung pada tahun 2010-2014. Kemudian penulis melanjutkan studi ke perguruan tinggi di Program Studi Pendidikan Guru Sekolah Dasar FKIP UKSW Salatiga pada tahun 2014. Kritik, saran maupun hal-hal yang berkaitan dengan kelanjutan atau pengembangan dari hasil penelitian ini bisa dikirim ke email penulis: 292014171@student.uksw.edu 